\title{
Long-term Creep Rupture Properties and Microstructure of $12 \%$ Cr Heat Resisting Steels ${ }^{*}$
}

\author{
By Ik-Min PARK** and Toshio FUJITA $A^{* * *}$
}

\begin{abstract}
Synopsis
Long-term creep rupture properties and microstructure of $12 \% \mathrm{Cr}$ heat resisting steels were investigated. It has been found that solid solution hardening by an addition of $\mathrm{Mo}$ is very effective on long-term creep rupture strength, but precipitation or dispersion hardening by an individual addition of $\mathrm{V}$ or $\mathrm{Nb}$ is little effective. Especially, the presence of excessive amounts of undissolved $\mathrm{NbG}$ leads to the coarsening of $M X$ precipitates, and a marked drop in long-term creep rupture strength. The combined addition of $\mathrm{V}+\mathrm{Nb}$ with $\mathrm{Mo}$ and $\mathrm{B}$ leads to superior $30000 \mathrm{~h}$ creep rupture strength. Microstructural differences between long-term crept specimens at $600^{\circ} \mathrm{C}$ and short-term crept specimens at $650^{\circ} \mathrm{C}$ were discussed by considering the parameter, $T(G+\log t)$. Long-term specimens at $600^{\circ} \mathrm{C}$ exhibit higher dislocation density substructure caused by intensive precipitation reactions which include both fresh precipitation within lath and agglomeration at boundaries, and exhibit intergranular fracture probably caused by stress concentration around the agglomerates, whereas short-term specimens at $650^{\circ} \mathrm{C}$ exhibit intragranular fracture. It is considered that the deviation of long-term creep rupture strength from the extrapolated value is caused by differences in precipitation hardening level and fracture mode.
\end{abstract}

\section{Introduction}

The precipitation hardening is widely applied to the current commercial heat resisting steels. In these steels, a complex microstructural change occurs during long-term service at elevated temperature, and ultimately fracture occurs after creep deformation. ${ }^{1)}$ In order to clarify these problems, some works ${ }^{2-4)}$ of the effects of microstructure on creep rupture properties have been carried out. However, these previous works were based on the short-term creep and rupture data, and did not give a satisfactory explanation for the time-dependent creep properties, such as the decrease in precipitation hardening and dispersion hardening caused by Ostwald ripening of the precipitates, ${ }^{\mathbf{5}, \mathbf{6})}$ or the decrease in solid solution hardening as a result of the precipitation of the solid solutes in long-term service.

In this work, to make further explanations for the relation between creep rupture properties and microstructure, long-term creep rupture properties and microstructure of $12 \% \mathrm{Cr}$ steels have been investigated using long-term specimens ruptured at 10000 $60000 \mathrm{~h}$. And microstructural differences between long-term crept specimens at $600^{\circ} \mathrm{C}$ and short-term crept specimens at $650^{\circ} \mathrm{C}$ have been studied by adopting the Larson-Miller parameter, $T(C+\log t)$. Furthermore, the effects of alloying elements on longterm creep rupture strength, microstructural changes during creep ${ }^{13)}$ (creep recovery process) were also discussed.

\section{Experimental Procedures}

Chemical analyses of the steels studied in this work are given in Table $1 . \mathrm{S} 1$ is a plain $12 \mathrm{Cr}$ steel, S2 and S3 are Mo and $\mathrm{V}$ individual by-added steels, respectively. The S4 S9 steels are complex alloyed steels containing $1.4 \% \mathrm{Mo}$ and B (S4 S6; $0.05 \%$, $\mathrm{S} 7 \sim \mathrm{S} 9 ; 0.03 \%$ ) with the variations in $\mathrm{V}$ and $\mathrm{Nb}$ contents.

These steels were cast into $40 \mathrm{~kg}$ ingots by air melting and forged at about $950 \sim 1100{ }^{\circ} \mathrm{C}$ to bars of 20 $\mathrm{mm}$ diameter. These steels were solution treated at $1150{ }^{\circ} \mathrm{C}$ for $30 \mathrm{~min}$ and oil quenched, and then tempered at $700{ }^{\circ} \mathrm{C}$ for $1 \mathrm{~h}$. Creep rupture specimens with a parallel gauge length of $30 \mathrm{~mm}$ were tested by conventional single specimen machines or multiple specimen machines. Determinations of Vickers hardness were made at room temperature using a $20 \mathrm{~kg}$ load.

The specimens for thin foils or other microstructural examinations were prepared from the gauge length of the ruptured specimens. Carbides were extracted in a $5 \% \mathrm{HCl}+95 \%$ ethanol solution at a current density of 0.02 to $0.03 \mathrm{~A} / \mathrm{cm}^{2}$. X-ray diffraction studies of extracted residues were made mainly using $\mathrm{Cu}-\mathrm{K}_{\alpha}$ radiations. Co powder $(a=3.545 \AA)$ was used as an internal standard for the lattice parameter measurements. The electron microprobe analyses (EPMA) of the residues were made at an accelerating voltage of $20 \mathrm{kV}$, specimen current of $0.05 \mu \mathrm{A}$, electron beam diameter of $70 \mu \mathrm{m}$, and measuring time of $10 \mathrm{sec}$.

Precipitation partition ratio is the ratio of the weight percent of an element in the extracted residue to that of the element in the steel. Electrolytic polishing for thin foils was performed in an $80 \% \mathrm{H}_{3} \mathrm{PO}_{4}+$ $20 \% \mathrm{CrO}_{3}$ solution, and for the final stages in a $135 \mathrm{~g} \mathrm{CH}_{3} \mathrm{COOH}+25 \mathrm{~g} \mathrm{CrO}_{3}+7 \mathrm{~g} \mathrm{H}_{2} \mathrm{O}$ solution at $0{ }^{\circ} \mathrm{C}$. Thin foils were examined in a $150 \mathrm{kV}$ electron microscope.

Carbon extraction replicas for EDX (Energy Dispersion X-ray analysis) examinations were prepared by etching initially in Villela's reagent and stripped in a $25 \% \mathrm{HCl}+25 \% \mathrm{HNO}_{3}+50 \%$ ethylene-glycol solution.

* Presented to the 97th ISIJ Meeting, April 1979, at The University of Tokyo in Tokyo. Manuscript received July $13,1981$. (C) 1982 ISIJ

** Graduate School, The University of Tokyo, Hongo, Bunkyo-ku, Tokyo 113.

*** Department of Materials Science, Faculty of Engineering, The University of Tokyo, Hongo, Bunkyo-ku, Tokyo 113. 
Table 1. Chemical composition of specimens. (wt\%)

\begin{tabular}{l|cccccccccccc}
\hline & G & Si & Mn & P & S & Ni & Gr & Mo & V & Nb & B & N \\
\hline S 1 & 0.22 & 0.43 & 0.83 & 0.007 & 0.012 & - & 10.56 & - & - & - & - & 0.037 \\
S 2 & 0.20 & 0.36 & 0.53 & 0.017 & 0.017 & 0.09 & 11.58 & 1.07 & - & - & - & 0.015 \\
S 3 & 0.20 & 0.44 & 0.53 & 0.005 & 0.005 & 0.08 & 11.85 & - & 0.38 & - & - & 0.015 \\
S 4 & 0.21 & 0.35 & 0.85 & 0.007 & 0.013 & 0.05 & 10.51 & 1.40 & - & - & 0.051 & 0.013 \\
S 5 & 0.20 & 0.31 & 0.89 & 0.007 & 0.014 & 0.05 & 10.40 & 1.40 & 0.20 & - & 0.042 & 0.015 \\
S 6 & 0.19 & 0.36 & 0.85 & 0.008 & 0.012 & 0.06 & 10.35 & 1.41 & - & 0.19 & 0.049 & 0.016 \\
S 7 & 0.20 & 0.32 & 0.84 & 0.008 & 0.010 & 0.05 & 10.72 & 1.44 & 0.25 & 0.08 & 0.027 & 0.016 \\
S 8 & 0.20 & 0.38 & 0.86 & 0.009 & 0.010 & 0.05 & 10.59 & 1.43 & 0.15 & 0.15 & 0.026 & 0.015 \\
S 9 & 0.20 & 0.38 & 0.83 & 0.009 & 0.009 & 0.05 & 10.73 & 1.37 & 0.12 & 0.20 & 0.028 & 0.017 \\
\hline
\end{tabular}

\section{Results}

\section{Long-term Creep Rupture Strength}

Results of creep rupture tests are shown in Figs. 1 and 2 as a function of the Larson-Miller parameter. The solid line was constructed based on the shortterm data up to $10000 \mathrm{~h}$, and long-term data beyond $10000 \mathrm{~h}$ were plotted.

In $\mathrm{S} 1 \sim \mathrm{S} 3$ steels, the long-term creep rupture strength is in the order: $\mathrm{S} 2>\mathrm{S} 3 \approx \mathrm{S} 1$. The addition of $\mathrm{Mo}$ is very effective on long-term creep rupture strength, whereas the addition of $\mathrm{V}$ is little effective.

In $\mathrm{S} 4 \sim \mathrm{S} 9$ steels, the long-term creep rupture strength is in the order: $\mathrm{S} 7>\mathrm{S} 8>\mathrm{S} 9>\mathrm{S} 6 \approx \mathrm{S} 5>\mathrm{S} 4$. The V-rich complex alloyed steel (S7) exhibits higher long-term $(30000 \mathrm{~h})$ creep rupture strength than the Nb-rich complex alloyed steel (S9). It should be noted that creep rupture strength of the Nb-rich steels decreases markedly at about $10000 \mathrm{~h}$.

\section{Precipitates}

The main precipitates of $12 \mathrm{Cr}$ steels in long-term creep tests is $\mathrm{M}_{23} \mathrm{C}_{6}$, which is the same as short-term creep tests. In Mo bearing steels, Laves phase $\left(\mathrm{Fe}_{2}\right.$ Mo) was identified in long-term specimens ruptured beyond $10000 \mathrm{~h}$. In long-term crept specimens, fine precipitates $(<0.2 \mu \mathrm{m})$ within laths or at lath boundaries, and agglomerates $(>1 \mu \mathrm{m})$ at prior austenite grain boundaries or lath boundaries were observed. The precipitates at lath boundaries or prior austenite grain boundaries were identified to be $\mathrm{M}_{23} \mathrm{C}_{6}$, and the precipitates within laths were identified to be $\mathrm{MC}$ and $\mathrm{M}_{23} \mathrm{C}_{6}$ by electron diffraction and EDX examinations (Photo. 1).

The typical carbide transformation in Cr containing steels, ${ }^{7)} \mathrm{M}_{7} \mathrm{C}_{3}-\mathrm{M}_{23} \mathrm{C}_{6}-\mathrm{M}_{6} \mathrm{C}$, was expected during long-term creep test. However, $\mathrm{M}_{6} \mathrm{C}$ was detected only in $\mathrm{S} 4$, whereas $\mathrm{M}_{7} \mathrm{C}_{3}$ was detected in long-term crept specimens of S2, S4 and S9 at $600{ }^{\circ} \mathrm{C}$.

$\mathrm{M}_{2} \mathrm{X}$ which has been reported $^{3,8)}$ to be the main secondary hardening precipitates of high $\mathrm{N}$ bearing $(>0.04 \% \mathrm{~N}) 12 \mathrm{Cr}$ steels was identified to be $\mathrm{Gr}_{2} \mathrm{~N}$ only in Sl, whose morphology changed from an acicular type to a planar or spherical type during longterm creep.

The precipitation partition ratio of $\mathrm{V}$ in $\mathrm{S} 3$ is about $60 \%$ after long-term creep test, and $\mathrm{V}$ is not contained in $\mathrm{M}$ of $\mathrm{M}_{23} \mathrm{C}_{6}$. Electron microprobe

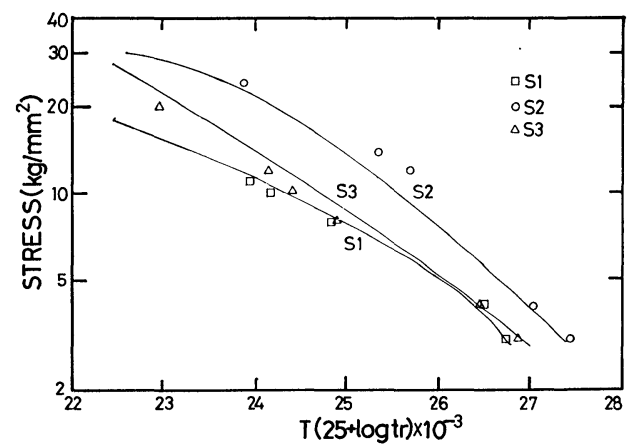

Fig. 1. Long-term creep rupture strength of S1 S3 steels. (Solid line was constructed based on short-term data up to $10000 \mathrm{~h}$, and long-term data beyond $10000 \mathrm{~h}$ were plotted.)

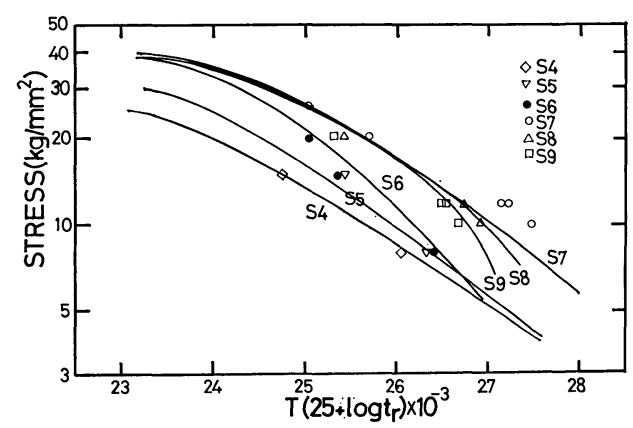

Fig. 2. Long-term creep rupture strength of S4 S9 steels. (Solid line was constructed based on short-term data up to $10000 \mathrm{~h}$, and long-term data beyond $10000 \mathrm{~h}$ were plotted.)

analyses by EDX showed that V-carbides contain small amounts of $\mathrm{Cr}$ (Photo. 2). In the Nb-rich $(>0.1 \% \mathrm{Nb})$ steels, MX $(a=4.39 \sim 4.43 \AA)$ was identified by X-ray diffraction. The lattice parameter of $\mathrm{MX}$ is almost the same as that of $(\mathrm{Nb}, \mathrm{V})(\mathrm{C}, \mathrm{N})$ $(a=4.432 \sim 4.440 \AA)$ reported by Hede and Aronsson, ${ }^{3)}$ but the metallic composition was found to be mainly $\mathrm{Nb}$ by EDX examinations (Photo. 1(c)). Laves phase $\left(\mathrm{Fe}_{2} \mathrm{Mo} ; a=4.72 \sim 4.75, c=7.67 \sim 7.75 \AA\right.$ ) identified by $\mathrm{X}$-ray diffraction can not be detected by electron diffraction or EDX examinations.

Amounts of precipitates, precipitation partition ratio of the individual alloying elements, and the lattic parameter of $\mathrm{M}_{23} \mathrm{C}_{6}$ are shown in Figs. 3(A) to (G) as a function of rupture time. As increasing the rup- 


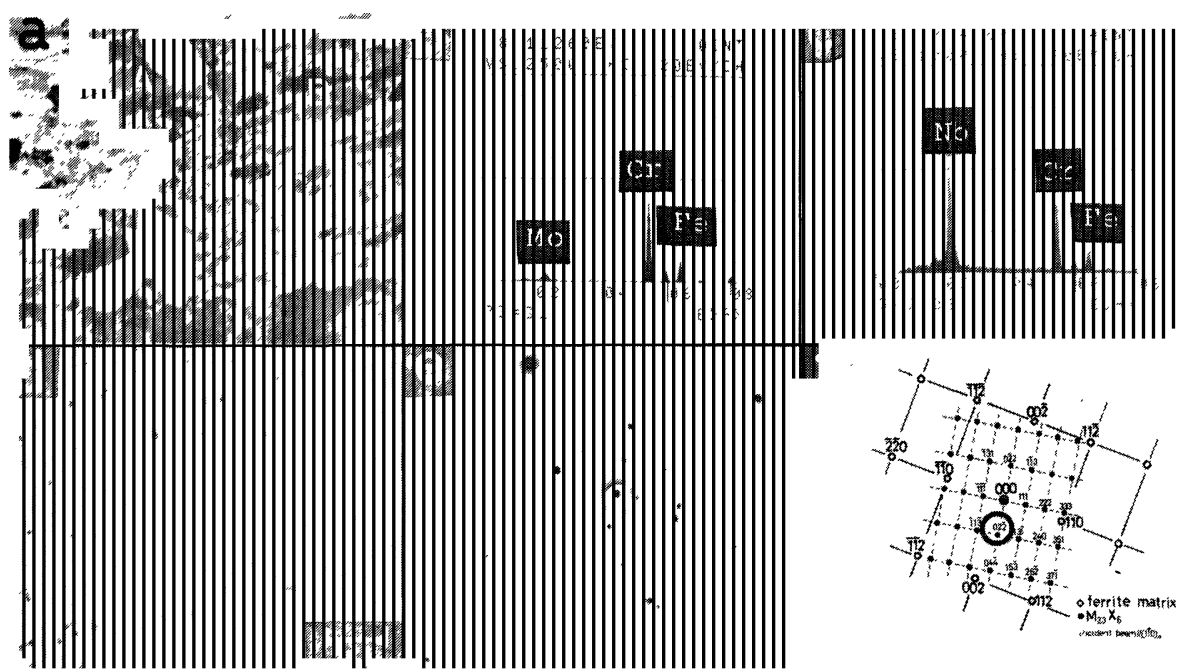

S7: $\quad 600^{\circ} \mathrm{C}, 20 \mathrm{~kg} / \mathrm{mm}^{2} \quad t_{r}=26223 \mathrm{~h}$

(a) Bright field image

(b) EDX spectrum showing the precipitation of $\mathrm{M}_{23} \mathrm{C}_{6}$ ( $A$ and $B$ type)

(c) EDX spectrum showing the precipitation of $\mathrm{MC}$

(C type, within lath)

(d) Dark field image ( $B$ type, at lath boundary)

(e) Electron diffraction pattern

(f) Key diagram

Photo. 1. Precipitation characteristics.

S3: $\quad 650^{\circ} \mathrm{G}, 3 \mathrm{~kg} / \mathrm{mm}^{2}$ $t_{r}=13864 \mathrm{~h}$ head region

(a) STEM image (extraction replica)

(b) EDX spectrum of $B$ precipitates $\left(\mathrm{M}_{23} \mathrm{C}_{6}\right)$

(c) EDX spectrum of $A$ precipitates (VC) Photo. 2. Precipitation characteristics.
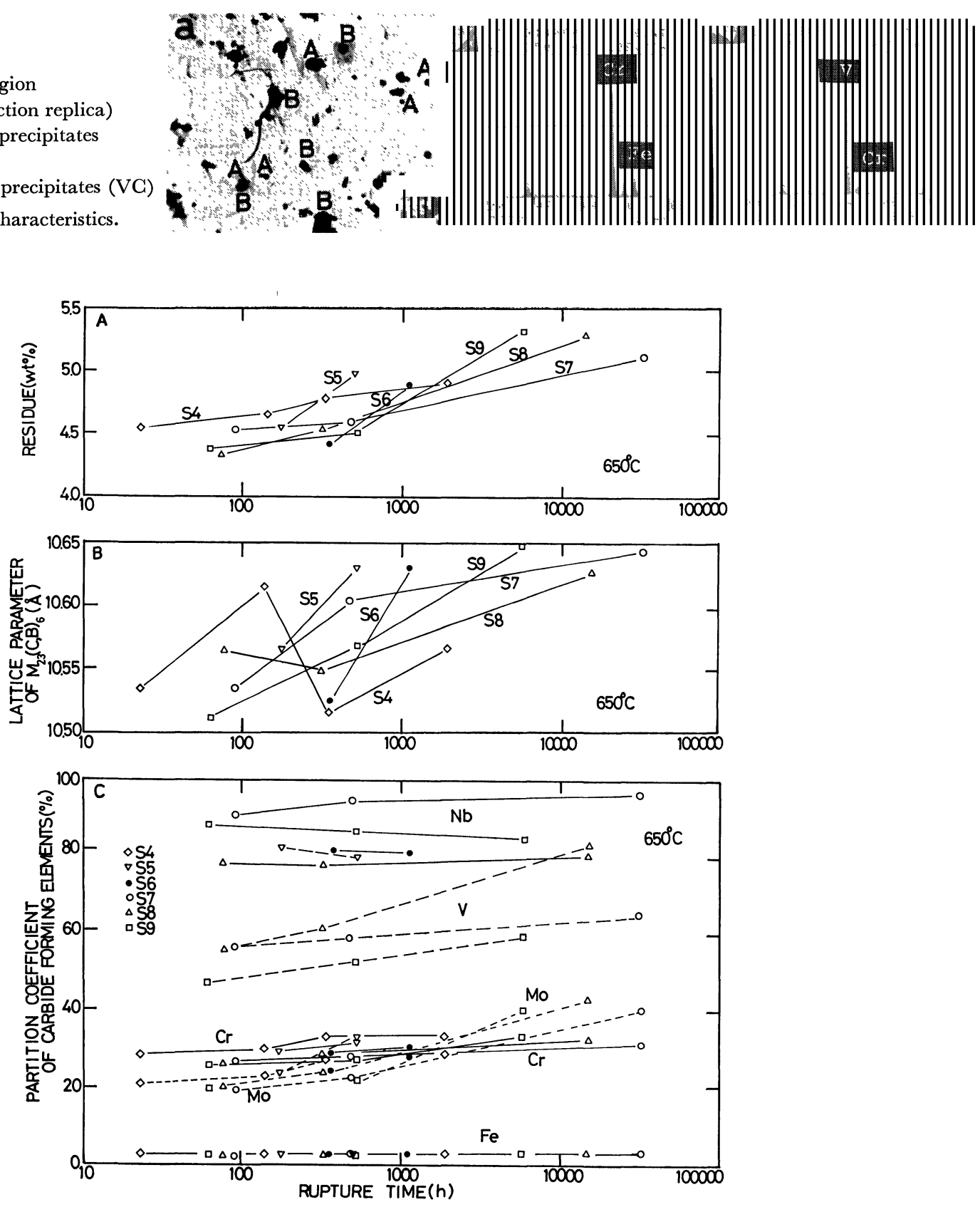

Fig. 3. Precipitation characteristics. 
ture time, amounts of precipitates and the lattice parameter of $\mathrm{M}_{23} \mathrm{C}_{6}$ increases. Precipitation partition ratio is in the order: $\mathrm{Nb}>\mathrm{V}>\mathrm{Cr}>\mathrm{Mo}>\mathrm{Fe}$. It will be noted that the precipitation partition ratio of $\mathrm{Mo}$ increases markedly in long-term test.

\section{Microstructure}

\section{Optical Microscopy}

Types of microstructure can be divided into two by the degree of creep recovery according to optical microscopy. Whilst the specimen with Vickers hardness (Hv) above 180 exhibits the tempered martensitic structure, the specimen with Vickers hardness below 180 no more exhibits the original tempered martensitic structure and prior austenite grain boundaries can not be distinguished (Photo. 3). Furthermore, recrystallized ferrite grains formed in long-term creep test, and decarburized surface regions depleted in $\mathrm{Cr}$ (with a width of about $50 \mu \mathrm{m}$ ) were observed.

\section{Transmission Microscopy}

Transmission micrographs (Photo. 4(a)) of the specimens, which no more exhibit the original tempered martensitic structure under an optical microscope, exhibit the creep recovery stage of subgrain growth. Transmission electron micrographs of the specimens with Vickers hardness above 180 exhibit the clear lath martensitic structure which have some polygonized regions. Microstructure of long-term crept specimens of $\mathrm{S} 7$ and $\mathrm{S} 9$ at 600 and $650^{\circ} \mathrm{C}$ are shown in Photo. 5. In the long-term crept specimens at $600{ }^{\circ} \mathrm{C}$, in spite of the agglomeration of $\mathrm{M}_{23} \mathrm{C}_{6}$ at boundaries, fine precipitates are dispersed within lath. In the long-term crept specimens at $650{ }^{\circ} \mathrm{C}$, subgrain growth is occurring with the coarsening of $\mathrm{M}_{23} \mathrm{C}_{6}$, and the fine precipitates within lath is markedly decreased. It will be noted that the creep recovery in S9 is accelerated by the marked coarsening of MX.

\section{Discussion}

\section{Long-term Creep Rupture Strength and Microstructure}

1. Microstructure and Parabola-like Decrease in Greep Rupture Curve

Stress-rupture time relations at 600 and $650{ }^{\circ} \mathrm{C}$ are shown in Figs. 4 and 5. The number in the figure indicates the rupture elongation. Creep rupture strength of the steels which exhibit low creep rupture strength in long-term tests at $600{ }^{\circ} \mathrm{C}$ (for example, S9) decrease markedly in intermediate-term tests at $650^{\circ} \mathrm{C}$. This marked decrease in creep rupture strength (parabola-like decrease in the stress-rupture time relation) is an important factor in the error of the extrapolation method. It is considered that this parabola-like decrease in the stress-rupture time relation is greatly dependent on both fracture mode changes and microstructural changes, such as the agglomeration of precipitates, subgrain formation, and recrystallization.

We discuss the above two changes during creep at the testing temperature of $650^{\circ} \mathrm{C}$. The Vickers hardness and lath width change (or the change of mean diameter of subgrain) as a function of rupture

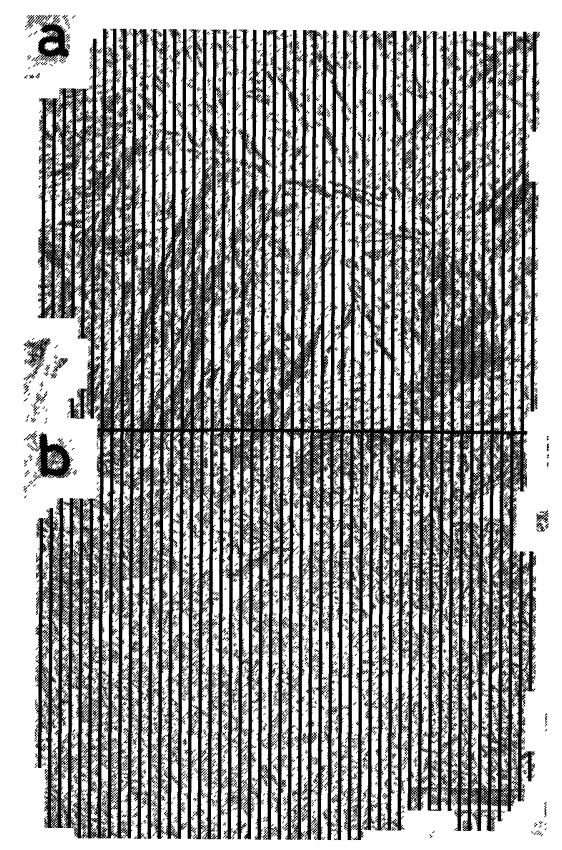

(a) S9: $600^{\circ} \mathrm{C}, 20 \mathrm{~kg} / \mathrm{mm}^{2}$ $t_{r}=10595 \mathrm{~h}(\mathrm{DPN}=238)$

(b) $\mathrm{S} 2: 650^{\circ} \mathrm{C}, 3 \mathrm{~kg} / \mathrm{mm}^{2}$ $t_{r}=57819 \mathrm{~h}(\mathrm{DPN}=163)$

Photo. 3. Optical micrographs.

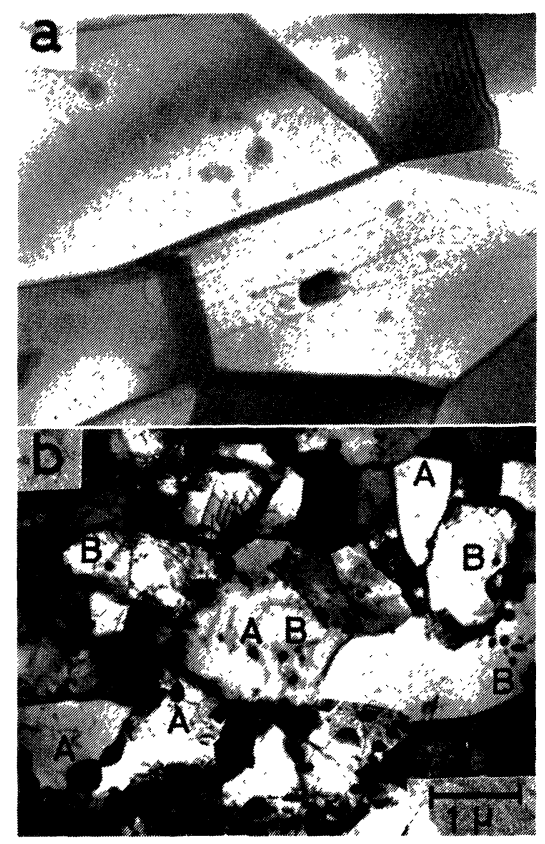

(a) $\mathrm{S} 2: 650^{\circ} \mathrm{C}, 3 \mathrm{~kg} / \mathrm{mm}^{2} t_{r}=57819 \mathrm{~h}$

(b) S6: $650^{\circ} \mathrm{G}, 16 \mathrm{~kg} / \mathrm{mm}^{2}$ $t_{r}=366 \mathrm{~h}\left(\mathrm{~A} ; \mathrm{M}_{23} \mathrm{C}_{6}, \mathrm{~B} ; \mathrm{MX}\right)$

Photo. 4. Transmission electron micrographs.

time are shown in Figs. 6 and 7. The change of Vickers hardness as a function of rupture time is similar to the relation of stress-rupture time. This indicates that Vickers hardness and lath width, which are greatly concerned with the degree of creep recovery, well correspond to the creep rupture strength at $650{ }^{\circ} \mathrm{C}$. All of the ruptured steels at $650^{\circ} \mathrm{C}$, with 


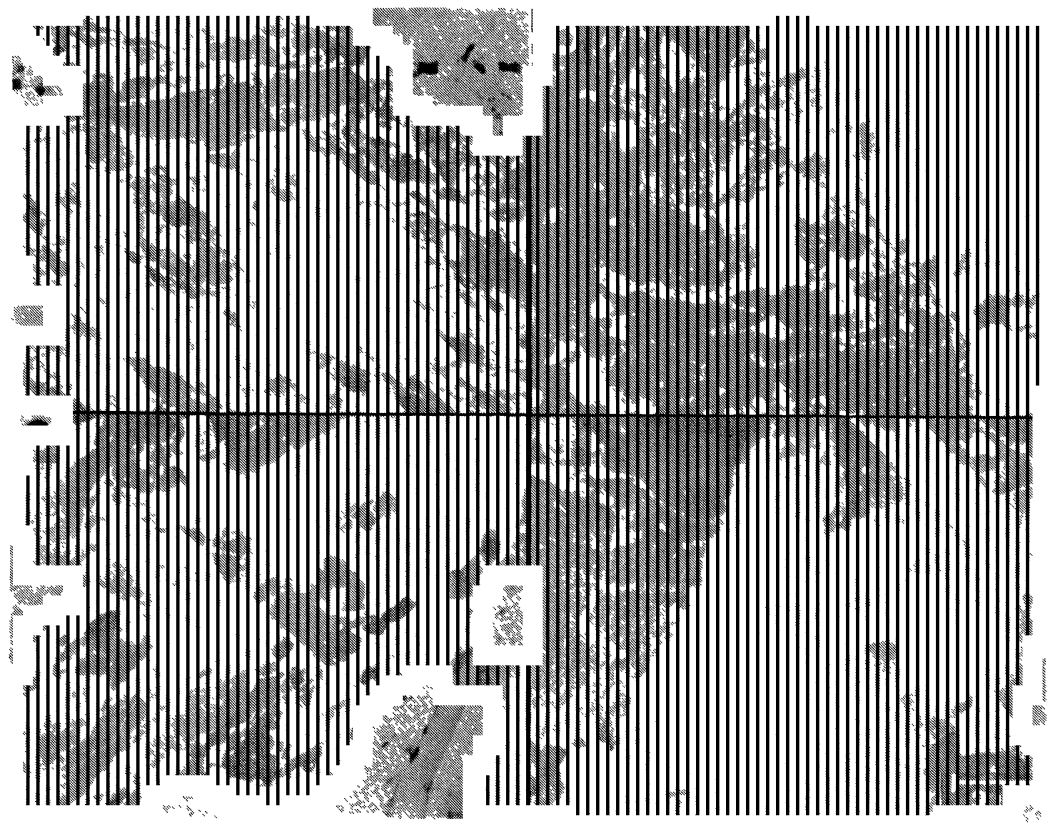

(a) S7: $600^{\circ} \mathrm{C}, 20 \mathrm{~kg} / \mathrm{mm}^{2} t_{r}=26223 \mathrm{~h}$

(b) $\mathrm{S} 9: 600^{\circ} \mathrm{C}, 20 \mathrm{~kg} / \mathrm{mm}^{2} t_{r}=10595 \mathrm{~h}$

(c) $\mathrm{S} 7: 650^{\circ} \mathrm{G}, 12 \mathrm{~kg} / \mathrm{mm}^{2} t_{r}=32070 \mathrm{~h}$

(d) $\mathrm{S} 9: 650^{\circ} \mathrm{C}, 12 \mathrm{~kg} / \mathrm{mm}^{2} t_{r}=6398 \mathrm{~h}$

Photo. 5.

Transmission electron micrographs.

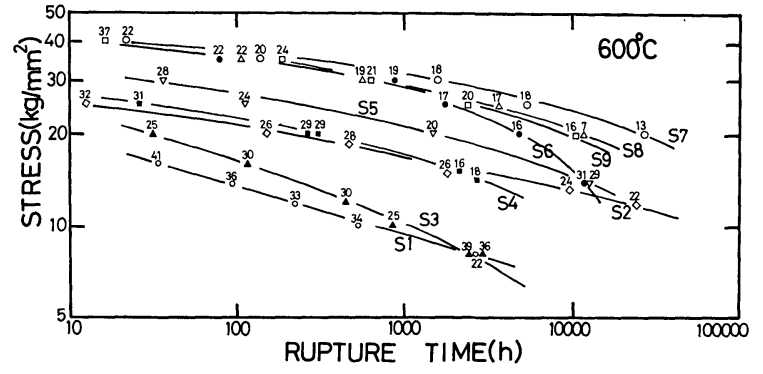

Fig. 4. Creep rupture properties at $600^{\circ} \mathrm{G}$.

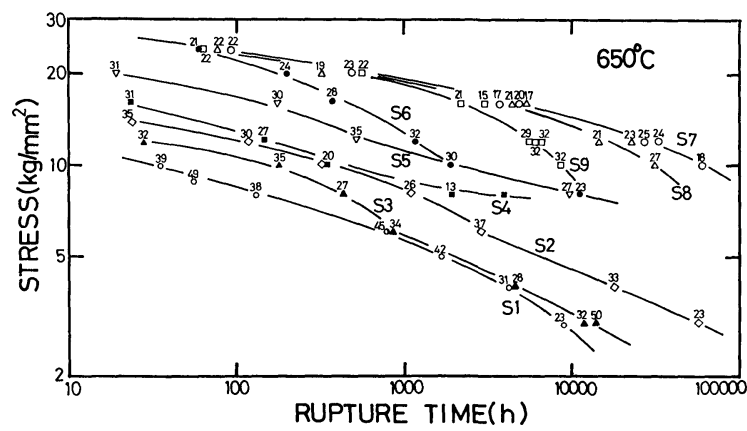

Fig. 5. Creep rupture properties at $650^{\circ} \mathrm{C}$.

an exception of $\mathrm{S} 4-8 \mathrm{~kg} / \mathrm{mm}^{2}$, exhibit typical transgranular ductile fracture surfaces (Photo. 7(a)). In the light of that, the parabola-like decrease in creep rupture strength at $650{ }^{\circ} \mathrm{C}$ is mainly attributed to the microstructural changes during creep rather than to the fracture mode changes.

In the steel which exhibits a marked drop in longterm creep rupture strength, microstructural changes, such as subgrain formation and subgrain growth markedly occur with the coarsening of the precipitates within laths. Electron micrographs (Photos. 4(b), $5(\mathrm{~b}), 5(\mathrm{~d})$ ) at the deviation point of linear extrapolation in the stress-rupture time relations, exhibit the creep recovery stage of subgrain growth with the coarsening of the precipitates at lath boundaries as a

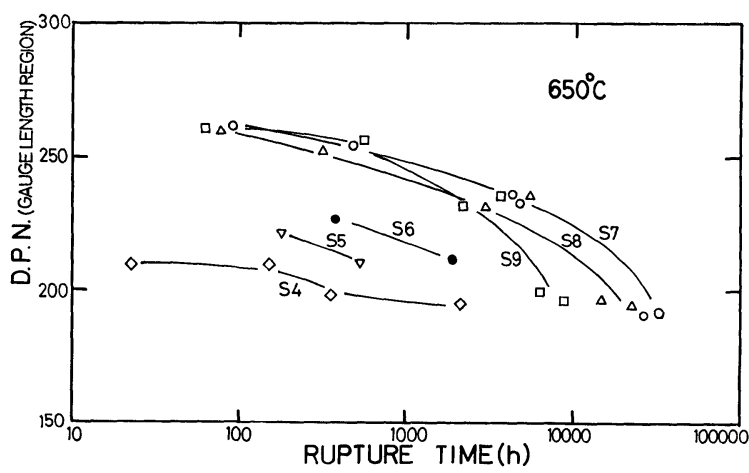

Fig. 6. The change of hardness at gauge length region as a function of rupture time.

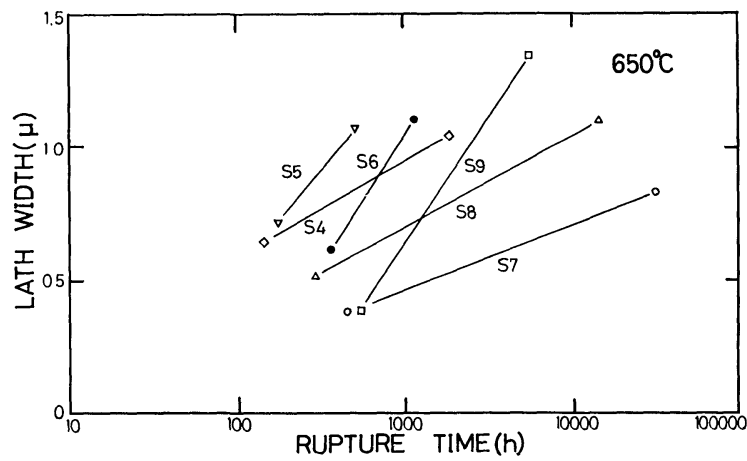

Fig. 7. The change of lath width as a function of rupture time.

result of the intensive lath boundary migration. The marked drop in long-term creep rupture strength of martensitic $12 \% \mathrm{Cr}$ steels at $650{ }^{\circ} \mathrm{C}$ is considered to be attributed to the subgrain growth (first recrystallization) with marked agglomerations of the precipitates within laths.

\section{Effect of Alloying Element on Microstructure}

The steels studied in this work have three different B content levels due to different melting process. It is well known that a minute addition of B astonish- 
ingly affects creep rupture strength. Boron addition generally leads to high creep rupture strength due to matrix dot precipitation of $\mathrm{M}_{23}(\mathrm{C}, \mathrm{B})_{6}$. However, it sometimes leads to low creep rupture strength due to the formation of undissolved $\mathrm{M}_{23}(\mathrm{C}, \mathrm{B})_{6} \cdot{ }^{15)}$ Unfortunately, the effect of $\mathrm{B}$ on long-term creep rupture strength is not apparent in this work. Here we only discuss the effect of $\mathrm{V}$ and $\mathrm{Nb}$ on long-term creep rupture strength of the same level of $B$ contents.

In long-term creep tests, Mo added steels (S2) exhibit much higher creep resistance than $\mathrm{V}$ added steels (S3). In short-term creep tests, Mo exhibits 1) substitutional solid solution hardening and IS effects ${ }^{5,9)}$ (chemical interaction between interstitial atoms and substitutional atoms) and 2) stabilizing effects of $\mathrm{M}_{23} \mathrm{C}_{6}$ by depressing the rate of Ostwald ripening as a result of the low diffusion rate of Mo contained in $\mathrm{M}_{23} \mathrm{G}_{6}$, whereas, in long-term tests, the attribution of precipitation hardening markedly decreases with the coarsening of the precipitates, and IS effects decreases as a result of the precipitation of interstitial solutes, and therefore the main strengthening mechanism becomes substitutional solid solution hardening. The precipitation partition ratio of $\mathrm{Mo}$ after long-term creep test (Fig. $3(\mathrm{C})$ ) is about $40 \%$, and therefore, $60 \%$ of Mo is in solution and exhibits solid solution hardening in long-term creep test. Effect of the Laves phase precipitation on long-term creep rupture strength can not be fully explained because $\mathrm{Fe}_{2} \mathrm{Mo}$ was identified by $\mathrm{X}$-ray diffraction alone in this work. According to the recent work, ${ }^{10)}$ the agglomeration rate of $\mathrm{Fe}_{2} \mathrm{Mo}$ is much higher than that of $\mathrm{M}_{23} \mathrm{C}_{6}$. Considering the decrease in solid solution hardening of Mo as a result of the precipitation of $\mathrm{Fe}_{2} \mathrm{Mo}$ together with the rapid agglomeration rate of $\mathrm{Fe}_{2} \mathrm{Mo}$, the precipitation of $\mathrm{Fe}_{2} \mathrm{Mo}$ is considered to be little effective on the long-term creep rupture strength. V exhibits dispersion hardening in shortterm tests, whereas in long-term tests dispersion hardening markedly decreases with the coarsening of $\mathrm{V}_{a} \mathrm{C}_{b}$ up to certain diameters. ${ }^{6}$,14) Transmission electron micrographs (Photo. 6) of S2 and S3 after long-term creep tests show that the creep recovery in $\mathrm{S} 2$ is greatly delayed due to the solid solution hardening of Mo, whereas the creep recovery in S3 is markedly accelerated with the coarsening of $\mathrm{V}_{a} \mathrm{C}_{b}$. It should be noted that substitutional solid solution hardening is the main strengthening mechanism in long-term creep tests where precipitation or dispersion hardening is no longer effective.

In complex alloyed steels (S4 S6) containing 1.4 $\% \mathrm{Mo}$ and $0.05 \% \mathrm{~B}$ with variations in $\mathrm{V}$ and $\mathrm{Nb}$ contents, creep rupture strength of Nb-added steels (S6) decreases markedly at about $10000 \mathrm{~h}$. In S7 S9 steels containing $1.4 \% \mathrm{Mo}$ and $0.03 \% \mathrm{~B}$ with variations in $\mathrm{V}$ and $\mathrm{Nb}$ contents, V-rich steels (S7) exhibit higher creep rupture strength than Nb-rich steels (S9). Alloying elements of $\mathrm{V}$ and $\mathrm{Nb}$ exhibit almost the same behavior in the point of dispersion hardening by similar types of MX precipitates. On the other hand, the solubility of $\mathrm{V}$ and $\mathrm{Nb}$ in austenite $^{11,12)}$ greatly differ. Considering the solubility

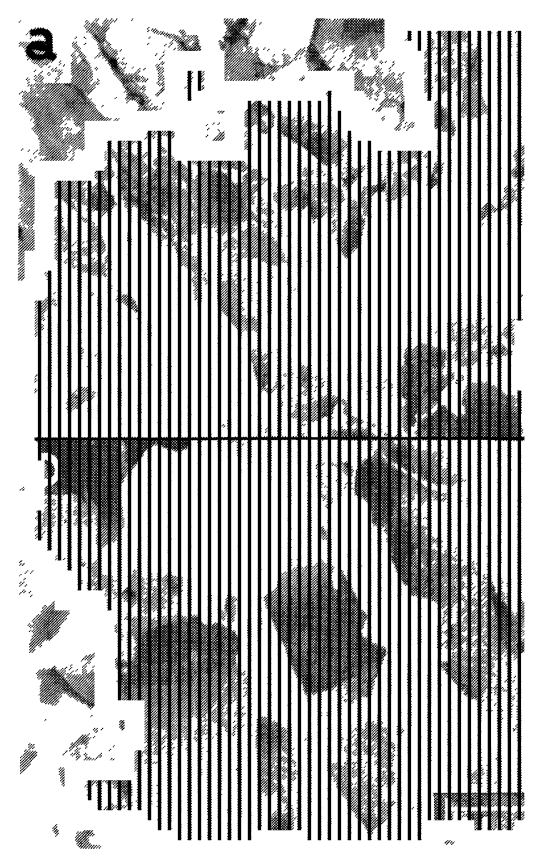

(a) $\mathrm{S} 2: 650^{\circ} \mathrm{C}, 3 \mathrm{~kg} / \mathrm{mm}^{2}$ $t_{r}=57819 \mathrm{~h}$ head region

(b) $\mathrm{S} 3: 650^{\circ} \mathrm{C}, 3 \mathrm{~kg} / \mathrm{mm}^{2}$ $t_{r}=13864 \mathrm{~h}$ head region

Photo. 6. Transmission electron micrographs.

of $\mathrm{V}$ and $\mathrm{Nb}$ in austenite in the case of $1150{ }^{\circ} \mathrm{C}$ solution treatments, added amount of $\mathrm{V}$ about $0.2 \%$ is completely in solution, whereas an addition of $\mathrm{Nb}$ above $0.04 \%$ leads to undissolved NbC. It is considered that this undissolved $\mathrm{NbC}$ accelerates the MX-MX agglomeration during creep, and this leads to a marked drop in creep rupture strength of $\mathrm{Nb}$ rich steels (S6, S9). V-rich steels (S7) exhibit higher $30000 \mathrm{~h}$ creep rupture strength than $\mathrm{Nb}$-rich steels (S9), which is probably attributed to the more fresh MX precipitation during creep and the lesser MXMX agglomeration of V-rich steels compared with Nb-rich steels.

\section{Microstructure and L.M. Extrapolation Method}

In order to extrapolate the long-term creep rupture strength, the Larson-Miller parameter is often used. In this section, we discuss whether there exists any microstructural differences or not between the specimens tested at 600 and $650{ }^{\circ} \mathrm{C}$ which have the same value of the Larson-Miller parameter, $T(C+\log t)$.

The comparison of microstructures between longterm crept specimens at $600{ }^{\circ} \mathrm{C}$ and short-term crept specimens at $650^{\circ} \mathrm{C}$ is shown in Table 2. In constant applied stress condition of $20 \mathrm{~kg} / \mathrm{mm}^{2}$, there seems to be little deviation in creep rupture strength between the experimental value at $600^{\circ} \mathrm{C}$ and the extrapolated value from the data at $650^{\circ} \mathrm{C}$. However, there are marked differences in microstructures between long-term crept specimens at $600{ }^{\circ} \mathrm{C}$ and short-term crept specimens at $650^{\circ} \mathrm{C}$.

Long-term crept specimens at $600^{\circ} \mathrm{C}$ have larger values, than short-term crept specimens at $650^{\circ} \mathrm{G}$, in the amounts of precipitates, the mean diameter of precipitates, the lattice parameter of $\mathrm{M}_{23} \mathrm{G}_{6}$, and 
Table 2. Microstructural differences between long-term crept specimens at $600^{\circ} \mathrm{C}$ and short-term crept specimens at $650^{\circ} \mathrm{C}$.

\begin{tabular}{|c|c|c|c|c|c|c|c|c|c|c|c|c|c|c|}
\hline \multirow{2}{*}{$\begin{array}{c}20 \\
\mathrm{~kg} / \\
\mathrm{mm}^{2}\end{array}$} & \multicolumn{2}{|c|}{$t_{r}(\mathrm{~h})$} & \multicolumn{2}{|c|}{$\begin{array}{l}T(25+\log t) \\
\quad \times 10^{-3}\end{array}$} & \multicolumn{2}{|c|}{ D.P.N. } & \multicolumn{2}{|c|}{$\begin{array}{l}\text { Lath width } \\
\qquad(\mu)\end{array}$} & \multicolumn{2}{|c|}{$\begin{array}{c}\text { Precipitates } \\
\text { amounts (wt \%) }\end{array}$} & \multicolumn{2}{|c|}{$\begin{array}{l}\text { Mean diameter } \\
\text { of ppts }(\mu)\end{array}$} & \multicolumn{2}{|c|}{$\begin{array}{l}\text { Lattice parameter } \\
\text { of } \mathrm{M}_{23} \mathrm{C}_{6}(\AA)\end{array}$} \\
\hline & $600^{\circ} \mathrm{C}$ & $650^{\circ} \mathrm{C}$ & $600^{\circ} \mathrm{C}$ & $650^{\circ} \mathrm{C}$ & $600^{\circ} \mathrm{C}$ & $650^{\circ} \mathrm{C}$ & $600^{\circ} \mathrm{C}$ & $650^{\circ} \mathrm{C}$ & $600^{\circ} \mathrm{C}$ & $650^{\circ} \mathrm{C}$ & $600^{\circ} \mathrm{C}$ & $650^{\circ} \mathrm{C}$ & $600^{\circ} \mathrm{C}$ & $650^{\circ} \mathrm{C}$ \\
\hline S 7 & 26223 & 498 & 25.68 & 25.56 & 286 & 257 & 0.31 & 0.37 & 5.48 & 4.58 & 0.147 & 0.109 & 10.640 & 10.595 \\
\hline S 8 & 11650 & 321 & 25.37 & 25.39 & 278 & 244 & 0.41 & 0.57 & 5.54 & 4.57 & 0.167 & 0.121 & 10.609 & 10.522 \\
\hline S 9 & 10595 & 568 & 25.34 & 25.62 & 281 & 254 & 0.38 & 0.49 & 5.43 & 4.47 & 0.188 & 0.124 & 10.587 & 10.569 \\
\hline
\end{tabular}

Vickers hardness at gauge length, and have smaller values in the mean width of martensite laths. That is, long-term crept specimens at $600{ }^{\circ} \mathrm{C}$ exhibit the marked delay in creep recovery in spite of agglomerations of precipitates. Volume fraction of precipitates in steel as a function of size is shown in Fig. 8. This figure shows that this marked delay of the creep recovery in long-term specimens at $600^{\circ} \mathrm{C}$ is attributed to the fresh precipitation of fine precipitates $(<0.2$ $\mu \mathrm{m})$ in long-term creep tests.

Considering the relation between the creep recovery level and creep rupture strength at $650{ }^{\circ} \mathrm{C}$ mentioned at Section $I V .1$, the creep rupture strength expected by these marked delays of recovery was not obtained at $600{ }^{\circ} \mathrm{C}$. This inconsistency between microstructure and creep rupture strength of long-term specimens at $600{ }^{\circ} \mathrm{C}$ can be explained in terms of the differences in fracture mode. The long-term crept specimens of S7 S9 steels at $600{ }^{\circ} \mathrm{C}-20 \mathrm{~kg} / \mathrm{mm}^{2}$ exhibit intergranular brittle fracture surface (Photo. 7 (b)) which was fractured along the agglomerates at prior austenite grain boundaries. This intergranular fracture is probably caused by stress concentration at the incoherent agglomerates at boundaries. It is considered that this intergranular fracture leads to a marked drop in creep rupture strength.

\section{Microstructural Change during Long-term Creep}

In our previous work, ${ }^{13)}$ the microstructural change during creep (creep recovery process) was modelized as a function of the L.M. parameter. According to that model, microstructure of long-term specimens at $600{ }^{\circ} \mathrm{C}$ was expected to be in the subgrain growth stage. However, the long-term specimens at $600{ }^{\circ} \mathrm{C}$ did not exhibit the subgrain growth stage. It should be noted that it is inadvisable to use the L.M. parameter for the estimation of microstructural changes during creep, if there is a possibility of a change in precipitation reactions with creep testing temperature.

Microstructural changes during long-term creep was established based on the long-term crept microstructure (Fig. 9). Transformation product of the oil quenched specimen is shown in Fig. 9(A). The substructure is a duplex structure of lath martensite and lower bainite. The prior austenite grain consisted of bundle and co-variant packet of martensite in which lath was observed. Small amounts of cementite and undissolved $\mathrm{NbC}$ were also observed within lath.

Microstructure of long-term crept specimens at $600{ }^{\circ} \mathrm{C}$ is shown in Fig. 9(B). In spite of the agglomeration at grain boundaries, the original lath martensitic structure remained due to continuing fresh pre-

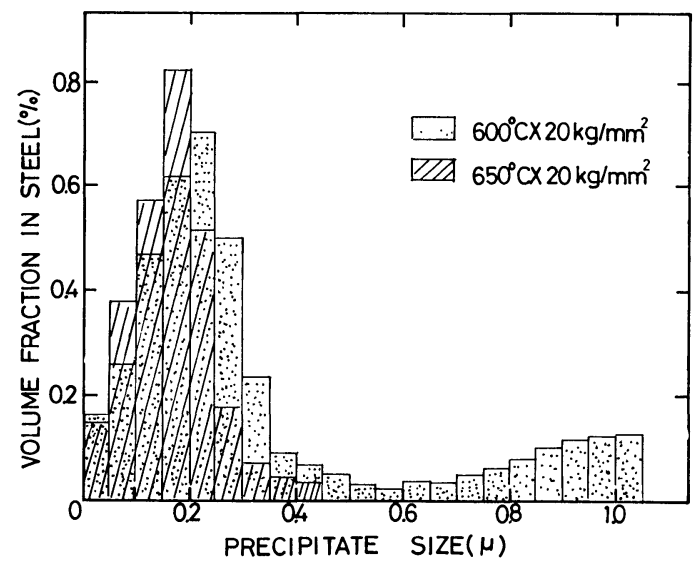

Fig. 8. Relation between precipitates size and volume fraction of precipitates for $\mathrm{S} 7$ steel.

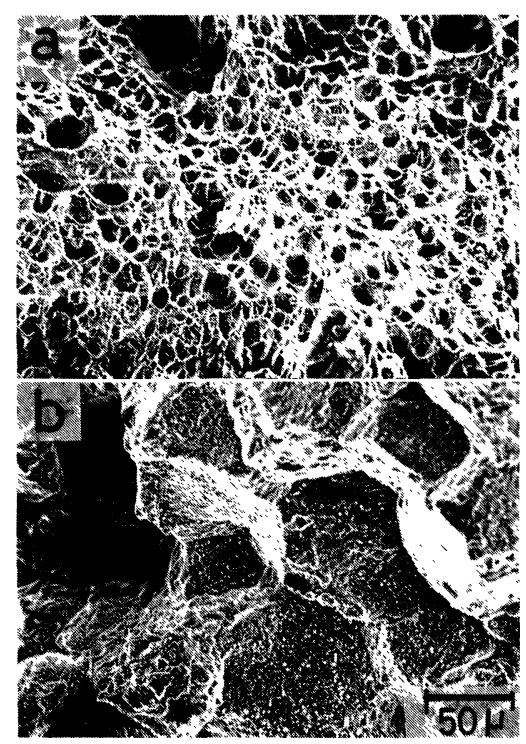

(a) S8: $650^{\circ} \mathrm{C}, 20 \mathrm{~kg} / \mathrm{mm}^{2} \quad t_{r}=321 \mathrm{~h}$

(b) S8: $600^{\circ} \mathrm{C}, 20 \mathrm{~kg} / \mathrm{mm}^{2} t_{r}=11650 \mathrm{~h}$

Photo. 7. Scanning electron micrographs.

cipitation of fine precipitates. Note that the marked agglomeration of $\mathrm{M}_{23} \mathrm{C}_{6}$ at packet boundaries occurs together with agglomeration at prior austenite grain boundaries.

Microstructure of long-term crept specimens at $650^{\circ} \mathrm{C}$ shows little differences from the model of previous work. As creep recovery continues, a secondary recrystallization nucleus which has a very low dislocation density is observed, and the original tempered martensitic substructure can not be distinguished even through an optical microscope. 
Fig. 9. Microstructure of the $12 \mathrm{CrMoVNb}$ steel after long-term creep test.
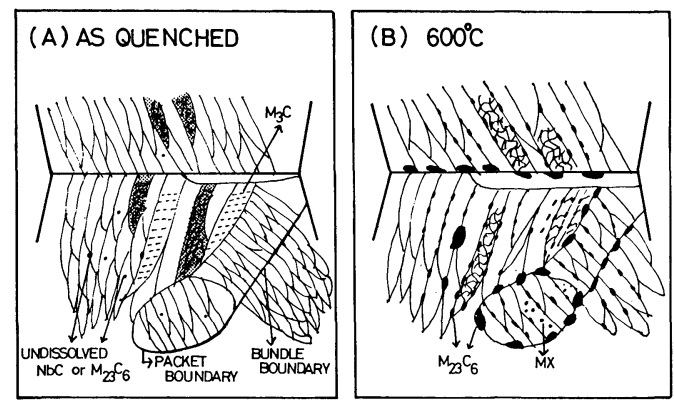

\section{Conclusions}

Long-term creep rupture strength and microstructure of $12 \mathrm{Cr}$ steels have been investigated with the specimens ruptured at $10000 \sim 60000 \mathrm{~h}$. The main results are as follows.

(1) Solid solution hardening by an addition of Mo is very effective on long-term creep rupture strength, but precipitation or dispersion hardening by an individual addition of $\mathrm{V}$ or $\mathrm{Nb}$ is little effective. Especially, the presence of excessive amounts of undissolved $\mathrm{NbC}$ leads to the coarsening of MX precipitates, and a marked drop in long-term creep rupture strength. The combined addition of $\mathrm{V}+\mathrm{Nb}$ with $1.5 \% \mathrm{Mo}$ and $0.03 \% \mathrm{~B}$ leads to superior $30000 \mathrm{~h}$ creep rupture strength. The V-rich $12 \mathrm{Cr}$ MoVNb steels have higher $30000 \mathrm{~h}$ creep rupture strengths than the Nb-rich steels, which is probably attributed to the more fresh MX precipitation during creep and the lesser MX-MX agglomeration of the V-rich steels.

(2) The marked parabola-like decrease in the creep rupture strength of $12 \mathrm{CrMoVNb}$ steels at 650 ${ }^{\circ} \mathrm{C}$ is well concerned with the microstructural changes, in particular, the subgrain growth stage (first recrystallization).

(3) Microstructural differences between long-term crept specimens at $650^{\circ} \mathrm{C}$ have been studied by adopting the Larson-Miller parameter, $T(C+\log t)$. Long-term crept specimens at $600{ }^{\circ} \mathrm{C}$ exhibit higher dislocation density substructure caused by intensive precipitation reactions which include both fresh precipitation within martensite lath and agglomeration at grain boundaries. On the other hand, long-term specimens at $600{ }^{\circ} \mathrm{C}$ exhibit the intergranular brittle fracture, whereas short-term specimens at $650^{\circ} \mathrm{C}$ exhibit the transgranular ductile fracture. It is considered that the deviation of long-term creep rupture strength from the extrapolated value is caused by differences in precipitation reactions and fracture mode.

\section{Acknowledgements}

The authors are grateful to Dr. Norio Takahashi, Mr. K. Asakura, Mr. T. Tsuchiyama, Mr. K. Nagai, Mr. M. Murakami for many helpful discussions and their encouragement throughout the work.

\section{REFERENGES}

1) J. Watanabe: Proceedings of the 23th Japan National Symposium on Strength, Fracture and Fatigue, Tokyo, (1978), 79.

2) E. A. Little, D. R. Harries and F. B. Pickering: Ferritic Steels for Fast Reactor Steam Generators, BNES, London, (1978), 136.

3) A. Hede and B. Aronsson: JISI, 207 (1969), 1241.

4) J. Koutsky: JISI, 205 (1967), 763.

5) B. B. Argent, M.N. van Niekerk and G. A. Redfern: JISI, 208 (1970), 830.

6) K. Suzuki, T. Nishi, T. Muta and T. Hirota: Trans. ISIJ, 11 (1971), 1.

7) M. Tanino: Bull. Japan Inst. Metals, 6 (1967), 23.

8) K. J. Irvine, D. J. Crowe and F. B. Pickering: JISI, 195 (1960), 386.

9) K. Monma, H. Sato and H. Kokita: J. Japan Inst. Metals, 29 (1965), 941.

10) S. Komatsu, M. Nakahashi, S. Nakamura and Y. Nakamura: Report of the 123rd Committee (Heat Resisting Metals and Alloys), Japan Society for the Promotion of Science (JSPS), 21 (1980), 1.

11) H. Nordberg and B. Aronsson: JISI, 206 (1968), 1263.

12) K. Narita: Bull. Japan Inst. Metals, 8 (1969), 49.

13) I. M. Park, T. Fujita and K. Asakura: Trans. ISIJ, 20 (1980), 99.

14) J. D. Baird, A. Jamieson, R. R. Preston and R. G. Cochrane: Creep Strength in Steel and High Temperature Alloys, The Metals Society, London, (1974), 207.

15) I. M. Park and T. Fujita: Trans. ISIJ, 20 (1980), B129. 